\title{
Effect of inoculation with arbuscular mycorrhizal fungi on growth, nutrient uptake and curcumin production of turmeric (Curcuma longa L.)
}

\author{
Kenji Yamawaki ${ }^{1}$, Atsushi Matsumura ${ }^{1^{*}}$, Rintaro Hattori ${ }^{1}$, Arata Tarui $^{1}$, \\ Mohammad Amzad Hossain ${ }^{2}$, Yoshiyuki Ohashi ${ }^{1}$, Hiroyuki Daimon ${ }^{1}$ \\ ${ }^{1}$ Graduate School of Life and Environmental Sciences, Osaka Prefecture University, Osaka, Japan; \\ *Corresponding Author: matsu@plant.osakafu-u.ac.jp \\ ${ }^{2}$ Faculty of Agriculture, University of the Ryukyus, Okinawa, Japan
}

Received 1 January 2013; revised 31 January 2013; accepted 7 February 2013

\begin{abstract}
Profitable turmeric (Curcuma longa L.) production requires adequate nutrients. We have investigated the effect of inoculation with arbuscular mycorrhizal fungi (AMF) on growth, nutrient uptake, yield and curcumin production of turmeric under field and glasshouse conditions. Although AMF inoculation slightly increased plant height, leaf number and shoot $\mathbf{N}$ content, no statistical differences were observed in vegetative growth parameters, biomass production, nutrient uptake and curcumin content compared to control plants under field conditions. It was difficult to determine the exact effect of inoculated AMF on turmeric growth because of indigenous AMF. On the other hand, turmeric showed better response to AMF inoculation under greenhouse conditions. AMF inoculation resulted in higher biomass production and nutrient uptake of turmeric. Moreover the concentration of curcumin, contained in the rhizome of turmeric, increased in AMF treatment. These results indicate that AMF inoculation has beneficial effects on turmeric growth and curcumin production. AMF inoculation to turmeric field would be effective when indigenous soil populations of AMF are low or native AMF are no longer effective.
\end{abstract}

Keywords: Arbuscular Mycorrhizal Fungi; Curcumin; Rhizome; Turmeric

\section{INTRODUCTION}

Curcuma longa L. belongs to the family Zingiberaceae, commonly known as turmeric, is an economically important plant cropped for its variety of uses such as con- diment, dye, drug and cosmetic. Over the past few decades, a considerable number of studies have been conducted on turmeric. Curcumin, which is active yellow pigment found in turmeric rhizome, has been known as a natural antioxidant with antitumor activity [1], an inhibitor of arachidonic acid metabolism [2], and a good antiinflammatory agent [3]. Previously, it was evaluated as a chemopreventive agent by the National Cancer Institute [4]. Due to increasing demand at medicinal properties, the social concern with turmeric has been growing for the last several years. Japan imports around 4000 tons of dried turmeric per year from India, China and other Asian countries. On the other hand, the domestic turmeric production is limited only about 100 tons of fresh one per year. Although turmeric growing area was limited in Okinawa islands and part of subtropical regions previously, it has been expanding gradually further to other regions in Japan.

Turmeric requires heavy nutrients for higher yields [5-7]. Especially, higher nitrogen $(\mathrm{N})$ application is effective for rhizome production [8]. But intensive input of organic and inorganic fertilizers is harming the environment. In Okinawa, a major turmeric cultivation area, high fertilizers input has been a leading cause of water pollution in coral reef seas. Furthermore the excess use of pesticide and herbicide is not recommended since turmeric is used as medicinal matter. Therefore it is necessary to promptly establish a sustainable turmeric production system with a lowered chemical input.

Soil microorganisms and their activities play important roles in transformation of plant nutrients from unavailable to available forms and also have many metabolic qualities related to soil fertility improvement [9]. Arbuscular mycorrhizal fungi (AMF) are obligate symbionts that colonize the roots of about $80 \%$ extant terrestrial plant species. In this relationship, AMF improve the host plant growth by increasing the uptake of water and 
minerals, especially the uptake of phosphorus $(\mathrm{P})$ which is readily fixed in soil, and in return, they obtain photosynthates from the host plants [10-12]. Recently, the beneficial effect of AMF on nitrogen (N) uptake by crop has been extensively studied [13,14]. Consequently, effective AMF utilization would lead to low-input sustainable turmeric cultivation systems.

There are few reports on the interaction of AMF and the family Zingiberaceae. Several studies have made on the biotrophic interaction between AMF and turmeric [15-18]. To our knowledge, the influence of AMF inoculation on turmeric growth and yield has not been studied.

Production of curcumin, a secondary compound, is important factor for C. longa. The biosynthesis of curcumin begins with phenylalanine which is converted into feruloyldiketide-coenzyme A (CoA), a precursor of curcumin, by diketide-CoA synthase. The synthesized feruloyldiketide-CoA is condensed with feruloyl-CoA by actions of curcmin syntase 1,2 and 3 to yield curcumin [19]. Some studies have demonstrated that AMF can influence secondary compounds such as phytohormone levels of jasmonate [20], terpenoids, carotenoids [21,22] and phenols [23] of host plant. Therefore, AMF inoculation offers the possibility of influence the concentration of the curcumin.

The use of AMF inoculation for natural plant production is still in its infancy and demands basic researches. In our experiment, a commercial product was used as AMF inoculant in anticipation of use in actual turmeric fields. Here, we expected that establishment of symbiotic relationship between turmeric and AMF would increase not only turmeric yield by stimulation of nutrients uptake but also improve the quality of turmeric by enhancing the curcumin concentration. The objectives of this study were to verify the contribution of AMF inoculation on growth, nutrition uptake, yield and curcumin production of turmeric under field and greenhouse conditions.

\section{MATERIALS AND METHODS}

\subsection{Field Experiment}

Field experiment was conducted from 25 May 2009 to 4 Jan 2010 at the Experimental farm on Osaka Prefecture University, in Sakai, Osaka, Japan. The experimental field $\left(12 \mathrm{~m}^{2}\right)$ was plowed well and then divided into 4 plots of $3 \mathrm{~m}^{2}(3 \mathrm{~m} \times 1 \mathrm{~m})$ size leaving $20 \mathrm{~cm}$ spacing between each plot. The chemical characteristics of the soil were as follows: $\mathrm{pH}\left(\mathrm{H}_{2} \mathrm{O}\right)$ of 4.8 , electrical conductivity (EC) of $0.07 \mathrm{dS} \cdot \mathrm{m}^{-1}$, total $\mathrm{C}$ of $9.38 \mathrm{~g} \cdot \mathrm{kg}^{-1}$, total $\mathrm{N}$ of $1.33 \mathrm{~g} \cdot \mathrm{kg}^{-1}$, inorganic $\mathrm{N}$ of $12.8 \mathrm{mg} \cdot \mathrm{kg}^{-1}$, total $\mathrm{P}$ of $0.76 \mathrm{~g} \cdot \mathrm{kg}^{-1}$, Truog-P of $71.4 \mathrm{mg} \cdot \mathrm{kg}^{-1}$. Corn (Zea maize cv. Gold dent KD850, Kaneko Seeds, Japan) was grown as preceding crop.
For turmeric plantlet preparation, about $30 \mathrm{~g}$ rhizome of Okinawa cultivar (Curcuma longa L.) in fresh weight was planted in a paper pot containing vermiculite on 25 May 2010 and grown in the greenhouse. Total 80 pots were prepared for this experiment. Half of those pots were inoculated with $3 \mathrm{~g}$ AMF commercial inoculums containing about 100 spores, Gigaspora margarita (Central Glass Co. Ltd, Tokyo, Japan). Control (non-inoculation) pots were prepared by mixing the same amounts of sterilized AMF inoculums, which were autoclaved 20 min at $121^{\circ} \mathrm{C}$, in the half of pot. Pre-germinated plantlets in control or AMF treatment were planted manually at a depth of $10 \mathrm{~cm}$ in a $30 \mathrm{~cm}$ triangular pattern in two rows on a ridge (planting density of 20 plants $3 \mathrm{~m}^{-2}$ ) in the field on 17 June 2010. Each treatment had two replications and 40 plantlets were planted respectively. Chemical fertilizer $\left(\mathrm{N}: \mathrm{P}_{2} \mathrm{O}_{5}: \mathrm{K}_{2} \mathrm{O}=8: 8: 8\right)$ at $83 \mathrm{~g} \cdot \mathrm{m}^{-2}$ was applied two times at 30 July 2010 and 29 August 2010. Overhead irrigation was given immediately after turmeric planting and fertilizer application. Weeds were removed manually.

At each sampling time, plants were separated into shoots and rhizomes. The plant parts were oven-dried at $80^{\circ} \mathrm{C}$ for 48 hours. After measurement of dry weight, the samples were ground into a fine powder. Total $\mathrm{N}$ was analyzed by vario MAX CN (Elementar, Germany). For phosphorus content, samples were ashed in a muddle furnace at $550^{\circ} \mathrm{C}$ and determined by the vanado molybdate colorimetric method. Curcumin concentration of rhizome was measured by the HPLC (LC-20AD ${ }_{\mathrm{XR}}$, Shimadzu, Japan). For mycorrhizal assessment, small parts of roots were sampled, washed, and stained by the technique of Phillips and Hayman [24]. Percentage of mycorrhizal colonization was determined using the grid-line intersection method [25].

\subsection{Pot Experiment}

Greenhouse experiment was conducted from 22 July 2011 to 19 November 2011 at the Experimental farm on Osaka Prefecture University, in Sakai, Osaka, Japan. About $20 \mathrm{~g}$ seed rhizome in fresh weight, surface sterilized by $2.5 \%$ sodium hypochlorite solution for $25 \mathrm{~min}$, was planted $8 \mathrm{~cm}$ deep in a $1 / 2000$ a Wagner pot filled with autoclaved $\left(60 \mathrm{~min}\right.$ at $\left.121^{\circ} \mathrm{C}\right)$ substrates: mix of 5 $\mathrm{kg}$ of Akadama soil (reddish soil; Heiwa, Japan), $1 \mathrm{~kg}$ of Kanuma soil (pale yellow soil; Heiwa, Japan) and $1 \mathrm{~kg}$ of fertilized granulated soil $\left(0.4 \mathrm{~g} \mathrm{~N} \mathrm{~kg}^{-1}, 1.0 \mathrm{~g} \mathrm{P}_{2} \mathrm{O}_{5} \mathrm{~kg}^{-1}\right.$ and $0.6 \mathrm{~g} \mathrm{~K}_{2} \mathrm{O} \mathrm{kg}^{-1}$; Kureha, Japan). The chemical characteristics of the soil were as follows: $\mathrm{pH}\left(\mathrm{H}_{2} \mathrm{O}\right)$ of 5.8 , $\mathrm{EC}$ of $0.26 \mathrm{mS} \mathrm{m}{ }^{-1}$, total $\mathrm{C}$ of $15.7 \mathrm{~g} \cdot \mathrm{kg}^{-1}$, total $\mathrm{N}$ of 1.2 $\mathrm{g} \cdot \mathrm{kg}^{-1}, \mathrm{NO}_{3}-\mathrm{N}$ of $290 \mathrm{mg} \cdot \mathrm{kg}^{-1}$, total $\mathrm{P}$ of $0.65 \mathrm{~g} \cdot \mathrm{kg}^{-1}$, Truog-P of $32.5 \mathrm{mg} \cdot \mathrm{kg}^{-1}$. Ten $\mathrm{g}$ of AMF inoculums mentioned above was inoculated into half of pots. The same amounts of sterilized AMF inoculums were mixed in the 
control treatment. The pots were arranged in a completely randomized block design with 12 replications. Liquid fertilizer, including $1.7 \mathrm{~g} \mathrm{~N}, 0.34 \mathrm{~g} \mathrm{P}_{2} \mathrm{O}_{5}$ and 2.59 $\mathrm{g} \mathrm{K}_{2} \mathrm{O}$, was applied at five-day intervals from 75 days after planting (DAP) to 95 DAP.

Plant height, number of leaf and number of stem were recorded from each treatment from 30 DAP to 120 DAP. SPAD value was measured on the top of two leaves by using SPAD-502 plus (Konica Minolta Optics, Japan) after liquid fertilizer application. Four plants of uniform size from both treatments were sampled two times $(60$ and 120 DAP). At each sampling time, plants were separated into shoots, roots and rhizomes, and oven-dried. Dry weight, $\mathrm{N}$ contents, $\mathrm{P}$ contents and curcumin concentration and contents, mycorrhizal colonization were investigated as mentioned above.

\subsection{Statistical Analysis}

The statistical difference was determined using paired or unpaired $t$-test. Mycorrhizal colonization data were arcsin transformed before analysis using $t$-test. Difference with $P<0.05$ was considered significant. Statistical analysis was performed using Excel Tokei 2008 software version 1.05 (SSRI Co Ltd, Tokyo, Japan).

\section{RESULTS AND DISCUSSION}

As shown in Table 1, biomass production, $\mathrm{N}$ and $\mathrm{P}$ content of shoot and rhizome with AMF treatment tended to be higher than in the control under field conditions. But there were no significances statistically throughout the experiment. AMF inoculation also had no effects on curcumin concentration and content of rhizome. Even though AMF inoculation was done, mycorrhizal colonization was not statistically different between treatments, where as a about $19 \%$ - 55\% colonization level was observed.

The effectiveness of AMF inoculation is affected by various environmental and biological factors, especially $P$ availability in soil and the inoculums potential of indigenous AMF. It is suggested that enhancement of mycorrhiza inoculum potential by a given preceding crop improves the mycorrhizal activity of a subsequent crop [26]. Corn, which was cultivated as preceding crop, is known to increase the population of indigenous AMF well. Other possibility is that AMF already infected rhizome. The AMF form obligate symbiotic association with not only the roots and but also other underground parts of most of the plants. There are findings on the natural colonization of underground parts of turmeric $[27,28]$. Consequently, an inoculants product is best used when there is reason to believe that indigenous soil populations of AMF are low or native AMF are no longer effective.

In greenhouse experiment, there were no differences in plant height, number of leaf and number of stem until fertilization (Figures 1(a)-(c)). After fertilization, however, these parameters were increased with AMF inoculation. Appearance of stem was observed soon in AMF treatment. SPAD value was also significantly higher in AMF treatment than that in control after fertilization (Figure 1(d)). Dry weight of shoot and rhizome in AMF was higher than those in control at 120 DAP (Table 2). Mycorrhizal colonization was found in only roots of plants inoculated with AMF. Although AMF infected turmeric roots at $60 \mathrm{DAP}$, there was no growth differences between treatments until 75 DAP.

Needless to say, the mere presence of AMF does not imply benefits to turmeric because the initial soil nutriaents were very low in pot experiment. After fertilization,

Table 1. Effect of arbuscular mycorrhizal fungi (AMF) on dry weight, $\mathrm{N}$ content and $\mathrm{P}$ content of shoot (ST), rhizome (RM), curcumin concentration (conc.) and curcumin content of Curcuma longa 60 days, 120 days and 201 days after transplanting (DAT) under field conditions.

\begin{tabular}{|c|c|c|c|c|c|c|c|c|c|c|}
\hline \multirow[t]{2}{*}{ Date } & \multirow[t]{2}{*}{ Treatment } & \multicolumn{2}{|c|}{$\begin{array}{c}\text { Dry weight } \\
\left(\mathrm{g} \cdot \mathrm{m}^{-2}\right)\end{array}$} & \multicolumn{2}{|c|}{$\begin{array}{c}\text { N content } \\
\left(\mathrm{g} \cdot \mathrm{m}^{-2}\right)\end{array}$} & \multicolumn{2}{|c|}{$\begin{array}{l}\text { P content } \\
\left(\mathrm{g} \cdot \mathrm{m}^{-2}\right)\end{array}$} & \multirow{2}{*}{$\begin{array}{l}\text { Curcumin } \\
\text { conc. } \\
(\%)\end{array}$} & \multirow{2}{*}{$\begin{array}{l}\text { Curcumin } \\
\text { content } \\
\left(\mathrm{g} \cdot \mathrm{m}^{-2}\right)\end{array}$} & \multirow{2}{*}{$\begin{array}{c}\text { Mycorrhizal } \\
\text { colonization } \\
(\%)\end{array}$} \\
\hline & & $\mathrm{ST}$ & $\mathrm{RM}$ & $\mathrm{ST}$ & $\mathrm{RM}$ & ST & $\mathrm{RM}$ & & & \\
\hline 16 August & Control & 121.3 & - & 3.1 & - & 0.6 & - & - & - & 54.1 \\
\hline \multirow[t]{2}{*}{ (60 DAT) } & $\mathrm{AMF}$ & 128.2 & - & 3.4 & - & 0.5 & - & - & - & 55.3 \\
\hline & Significance $^{\mathrm{z}}$ & ns & - & ns & - & $\mathrm{ns}$ & - & - & - & ns \\
\hline 15 October & Control & 272.0 & 243.8 & 3.9 & 2.1 & 0.8 & 1.0 & 0.36 & 0.9 & 33.7 \\
\hline \multirow[t]{2}{*}{$(120 \mathrm{DAT})$} & $\mathrm{AMF}$ & 263.6 & 266.0 & 3.8 & 2.7 & 0.9 & 1.2 & 0.33 & 0.9 & 18.9 \\
\hline & Significance & ns & ns & ns & ns & $\mathrm{ns}$ & ns & $\mathrm{ns}$ & ns & ns \\
\hline 4 January & Control & 247.5 & 515.7 & 1.9 & 8.4 & 0.3 & 2.1 & 0.20 & 1.0 & - \\
\hline \multirow[t]{2}{*}{ (201 DAT) } & $\mathrm{AMF}$ & 270.7 & 594.6 & 2.2 & 9.8 & 0.3 & 2.4 & 0.20 & 1.2 & - \\
\hline & Significance & ns & ns & ns & ns & $\mathrm{ns}$ & ns & ns & $\mathrm{ns}$ & - \\
\hline
\end{tabular}

${ }^{\mathrm{z}} \mathrm{ns}$ represents non-significance at $5 \%$ level by $t$-test. 
Table 2. Effect of arbuscular mycorrhizal fungi (AMF) on dry weight, $\mathrm{N}$ content and $\mathrm{P}$ content of shoot (ST), rhizome (RM), curcumin concentration (conc.) and curcumin content of Curcuma longa 60 days and 120 days after planting (DAP) under greenhouse conditions.

\begin{tabular}{|c|c|c|c|c|c|c|c|c|c|c|c|c|c|}
\hline \multirow{2}{*}{ Date } & \multirow{2}{*}{ Treatment } & \multicolumn{3}{|c|}{$\begin{array}{l}\text { Dry weight } \\
\left(\mathrm{g} \cdot \text { plant }^{-1}\right)\end{array}$} & \multicolumn{3}{|c|}{$\begin{array}{l}\mathrm{N} \text { content } \\
\left(\mathrm{mg} \cdot \text { plant }^{-1}\right)\end{array}$} & \multicolumn{3}{|c|}{$\begin{array}{c}\text { P content } \\
\left(\mathrm{mg} \cdot \text { plant }^{-1}\right)\end{array}$} & \multirow{2}{*}{$\begin{array}{l}\text { Curcumin } \\
\text { conc. (\%) }\end{array}$} & \multirow{2}{*}{$\begin{array}{c}\text { Curcumin } \\
\text { content } \\
\left(\mathrm{mg} \cdot \text { plant }^{-1}\right)\end{array}$} & \multirow{2}{*}{$\begin{array}{c}\text { Mycorrhiza } \\
\text { colonization } \\
(\%)\end{array}$} \\
\hline & & ST & $\mathrm{RM}$ & RT & ST & $\mathrm{RM}$ & $\mathrm{RT}$ & ST & $\mathrm{RM}$ & $\mathrm{RT}$ & & & \\
\hline \multirow[t]{3}{*}{60 DAP } & Control & 6.0 & - & 2.8 & 148.2 & - & 28.8 & 9.5 & - & 7.4 & - & - & $\mathrm{nd}^{\mathrm{y}}$ \\
\hline & AMF & 5.9 & - & 2.3 & 155.0 & - & 27.8 & 13.5 & - & 6.1 & - & - & 30.6 \\
\hline & Significance $^{z}$ & ns & - & ns & ns & - & ns & ns & - & ns & - & - & - \\
\hline \multirow[t]{3}{*}{120 DAP } & Control & 8.4 & 12.0 & 5.2 & 195.6 & 211.7 & 41.0 & 5.6 & 8.9 & 7.7 & 0.12 & 14.9 & nd \\
\hline & AMF & 11.2 & 20.2 & 5.8 & 296.6 & 327.4 & 52.8 & 20.9 & 39.8 & 9.8 & 0.16 & 31.7 & 87.2 \\
\hline & Significance & $*$ & ${ }^{*}$ & $\mathrm{~ns}$ & ${ }^{*}$ & ${ }^{*}$ & $\mathrm{~ns}$ & $*$ & * & $\mathrm{ns}$ & $*$ & ${ }^{*}$ & - \\
\hline
\end{tabular}

${ }^{\mathrm{z}} \mathrm{ns}$ and ${ }^{*}$ represent non-significance and significance at $5 \%$ level by $t$-test; ${ }^{\mathrm{y}}$ nd indicates not detected.

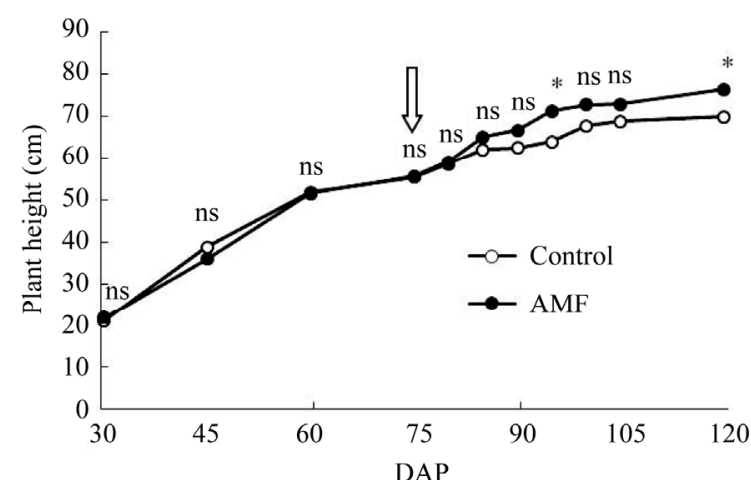

(a)

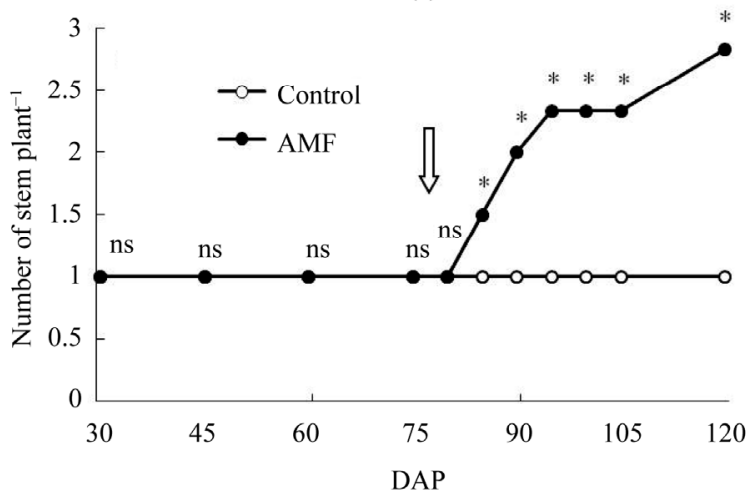

(c)

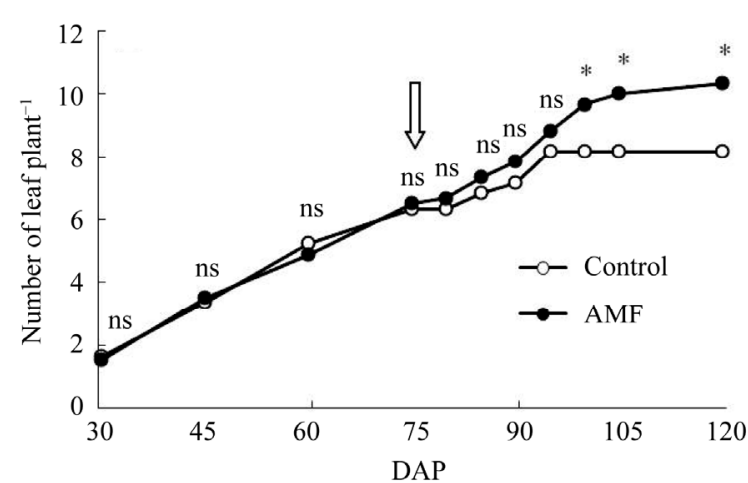

(b)

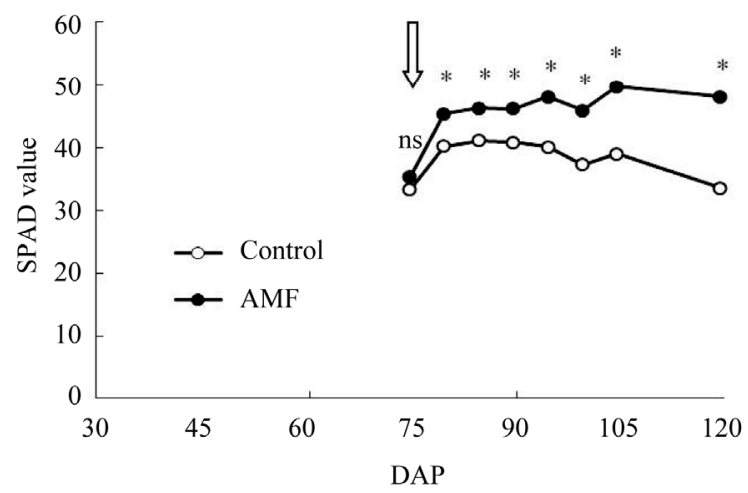

(d)

Figure 1. Effects of arbuscular mycorrhizal fungi (AMF) inoculation on plant height (a), number of leaf (b), number of stem (c) and SPAD value (d) of turmeric in pot experiment. Arrow indicates the date when liquid fertilizer was applied. Data are means of 8 replications from 30 DAP to 60 DAP and 6 replications from 75 DAP to 120 DAP, respectively. ns and * represent non-significance and significance at $5 \%$ level by $t$-test.

the growth of AMF inoculated turmeric was extremely stimulated. $\mathrm{N}$ content was significantly increased at 120 DAP, approximately 1.5 -fold. P content followed similar patterns as $\mathrm{N}$ content. $\mathrm{P}$ content was higher in AMF treatment than control, approximately 2-fold. AMF scavenged supplied nutrients, mainly phosphorus from the soil into the root system through extraradical hyphae.

The mean curcumin concentration of AMF treatment was $0.16 \%$, which was significantly higher $(P<0.05)$ than that of control $(0.13 \%)$. The curcumin content was also higher in AMF treatment. Our hypothesis that AMF would influence curcumin concentration and content was supported by the data obtained. $\mathrm{P}$ is one of the main nutrients involved in the synthesis of secondary metabolites as their production demands ATP [29]. The increase in availability of $\mathrm{P}$ through mycorrhizal association would 
probably underlie the increase of curcumin. Similarly, Silva et al. [30] in their work on ginger inoculated AMF found oil concentration was modulated according to AMF. At the moment we are unable to propose a mechanism explaining how AMF influence turmeric curcumin production. Although turmeric varieties may have a great effect on the curcumin concentration, the increase of curcumin, which determines quality and international market price of turmeric, by AMF inoculation is an important finding.

Mycorrhizal associations with plants have evolved in complex and relatively stable natural environments. Now we seek to manage this symbiosis in agricultural systems. In Japan, most turmeric is cultivated by the avoidance of chemical biocides and soluble inorganic fertilizers. It is often assumed that AMF will play a more pivotal role in alternative systems than in conventional systems. Our results indicate that the use of mycorrhizal inoculation is a feasible approach for turmeric production. The greenhouse experiment suggests that AMF inoculation can increase turmeric growth and rhizome production significantly. In our experiment G. margarita, included in commercial inoculums, was used. But the genus Glomus is more frequently found in the fertile agricultural soils [31]. On the other hand, the genus Gigaspora is more abundant in low-nutrient or nutrient-binding soils [32,33]. It is suggested that different AMF isolates influence the host plant growth and qualitative differences in the secondary metabolites. Therefore further studies are needed for selection of effective AMF for turmeric growth and curcumin production.

\section{AKNOWLEDGEMENTS}

This study was supported in part by Mext, Kakenhi, Japan (No. 20248003). We thank Okinawa Prefectural Agricultural Research Center and Instrumental Research Center, University of the Ryukyus, for technical assistance of curcumin analysis by HPLC. We are also grateful to the technical staff of Osaka Prefecture University Farm for their help in field experiment.

\section{REFERENCES}

[1] Ruby, A.J., Kuttan, G., Babu, K.D., Rajasekharan, K.N. and Kuttan, R. (1995) Anti-tumour and antioxidant activity of natural curcuminoids. Cancer Letters, 94, 79-83. doi:10.1016/0304-3835(95)03827-J

[2] Conney, A.H., Lysz, T., Ferraro, T., Abidi, T.F., Manchand, P.S., Laskin, J.D. and Huang, M.T. (1991) Inhibitory effect of curcumin and some related dietary compounds on tumour promotion and arachidonic acid metabolism in mouse skin. Advances in Enzyme Regulation, 31, 385396. doi:10.1016/0065-2571(91)90025-H

[3] Mukhopadhyay, A., Basu, N., Ghatak, N. and Gujral, P.K. (1982) Anti-inflammatory and irritant activities of curcumin analogues in rats. Agents Actions, 12, 508-515.

\section{doi:10.1007/BF01965935}

[4] Kelloff, G.J., Boone, C.W., Crowell, J.A., Steele, V.E., Lubet, R. and Sigman, C.C. (1994) Chemopreventive drug development: Perspective and progress. Cancer Epidemiology, Biomarkers and Prevention, 3, 85-98.

[5] Govind, S., Gupta, P.N. and Chandra, R. (1990) Response of $\mathrm{N}$ and $\mathrm{P}$ levels on growth and yield components of turmeric in acid soils of Meghalaya. Indian Journal of Horticulture, 47, 79-84.

[6] Yamgar, V.T., Kathmale, D.K., Belhekar, P.S., Patil, R.C. and Paul, P.S. (2001) Effect of different levels of nitrogen, phosphorus and potassium and split application of $\mathrm{N}$ on growth and yield of turmeric (Curcuma longa). Indian Journal of Agronomy, 46, 372-374.

[7] Jagadeeswaran, R., Murugappan, V. and Govindaswamy, M. (2005) Effect of slow release NPK fertilizer sources on the nutrient use efficiency in turmeric (Curcuma longa L.). World Journal of Agricultural Sciences, 1, 65-69.

[8] Hossain, M.A. and Ishimine, Y. (2007) Effects of farmyard manure on growth and yield of turmeric (Curcuma longa L.) cultivated in dark-red soil, red soil and gray soil in Okinawa, Japan. Plant Production Science, 10, 146150. doi:10.1626/pps.10.146

[9] Leaungvutiviroj, C., Piriyaprin, S., Limtong, P. and Sasaki, K. (2010) Relationships between soil microorganisms and nutrient contents of Vetiveria zizanioides (L.) Nash and Vetiveria nemoralis (A.) Camus in some problem soils from Thailand. Applied Soil Ecology, 46, 95102. doi:10.1016/j.apsoil.2010.06.007

[10] Newsham, K.K., Fitter, A.H. and Watkinson, A.R. (1995) Multi-functionality and biodiversity in arbuscular mycorrhizas. Trends in Ecology and Evolution, 10, 407-411. doi:10.1016/S0169-5347(00)89157-0

[11] Clark, R.B., Zeto, S.K. and Zobel, R.W. (1999) Arbuscular mycorrhizal fungal isolate effectiveness on growth and root colonization of Panicum virgatum in acidic soil. Soil Biology and Biochemistry, 31, 1757-1763. doi:10.1016/S0038-0717(99)00084-X

[12] Wang, B. and Qui, Y.L. (2006) Phylogenetic distribution and evolution of mycorrhizas in land plants. Mycorrhiza, 16, 299-363. doi:10.1007/s00572-005-0033-6

[13] Guether, M., Neuhäuser, B., Balestrini, R., Dynowski, M., Ludewig, U. and Bonfante, P. (2009) A mycorrhizal-specific ammonium transporter from Lotus japonicus acquires nitrogen released by arbuscular mycorrhizal fungi. Plant Physiology, 150, 73-83. doi:10.1104/pp.109.136390

[14] Leigh, J., Hodge, A. and Fitter, A.H. (2009) Arbuscular mycorrhizal fungi can transfer substantial amounts of nitrogen to their host plant from organic material. New Phytologist, 181, 199-207. doi:10.1111/j.1469-8137.2008.02630.x

[15] Muthukumar, T., Senthikumar, M., Rajangam, M. and Udaiyan, K. (2006) Arbuscular mycorrhizal morphology and dark septate fungal associations in medicinal and aromatic plants of western Ghats, southern India. Mycorrhiza, 17, 11-24. doi:10.1007/s00572-006-0077-2

[16] Mridha, M.A.U. and Dhar, P.P. (2007) Biodiversity of arbuscular mycorrhizal colonization and spore population 
in different agroforestry trees and crop species growing in Dinajpur, Bangladesh. Journal of Forestry Research, 18, 91-96. doi:10.1007/s11676-007-0018-8

[17] Sumathi, C.S., Balasubramanian, V., Ramesh, N. and Kannan, V.R. (2008) Influence of biotic and abiotic features on Curcuma longa L. plantation under tropical condition. Middle-East Journal of Scientific Research, 3, 171-178.

[18] Radhika, K.P. and Rodrigues, B.F. (2010) Arbuscular mycorrhizal fungal diversity in some commonly occurring medicinal plants of western Ghats, goa region. Journal of Forestry Research, 21, 45-52. doi:10.1007/s11676-010-0007-1

[19] Katsuyama, Y., Kita, T. and Horinouchi, S. (2009) Identification and characterization of multiple curcumin synthases from the herb Curcuma longa. FEBS Letters, 583, 2799-2803. doi:10.1016/j.febslet.2009.07.029

[20] Hause, B., Maier, W., Miersch, O., Kramell, R. and Strack, D. (2002) Induction of jasmonate biosynthesis in arbuscular mycorrhizal barley roots. Plant Physiology, 130, 1213-1220. doi:10.1104/pp.006007

[21] Akiyama, K., Matsuoka, H. and Hayashi, H. (2002) Isolation and identification of a phosphate deficiency-induced C-glycosylflavonoid that stimulates arbuscular mycorrhiza formation in melon roots. Molecular Plant-Microbe Interactions, 15, 334-340. doi:10.1094/MPMI.2002.15.4.334

[22] Fester, T., Schmidt, D., Lohse, S., Walter, M.H., Giuliano, G., Bramley, P.M., Fraser, P.D., Hause, B. and Strack, D. (2002) Stimulation of carotenoied metabolism in arbuscular mycorrhizal roots. Planta, 216, 148-154. doi:10.1007/s00425-002-0917-Z

[23] Zhu, H.H. and Yao, Q. (2004) Localized and systemic increase of phenols in tomato roots induced by Glomus versiforme inhibits Ralstonia solanacearum. Journal of Phytopathology, 152, 537-542. doi:10.1111/j.1439-0434.2004.00892.x

[24] Phillips, J.M. and Hayman, D.S. (1970) Improved procedures for clearing roots and staining parasitic and vesicular-arbuscular mycorrhizal fungi for rapid assessment of infection. Transactions of the British Mycological Society,

\section{5, 158-161. doi:10.1016/S0007-1536(70)80110-3}

[25] Giovannetti, M. and Mosse, B. (1980) An evaluation of techniques for measuring vesicular arbuscular mycorrhizal infection in roots. New Phytologist, 84, 489-500. doi:10.1111/j.1469-8137.1980.tb04556.X

[26] Karasawa, T., Kasahara, Y. and Takebe, M. (2002) Differences in growth responses of maize to preceding cropping caused by fluctuation in the population of indigenous arbuscular mycorrhizal fungi. Soil Biology and Biochemistry, 34, 851-857. doi:10.1016/S0038-0717(02)00017-2

[27] Iqbal, S.H. and Nasim, G. (1991) Are under ground nonroot portions of tropical plants vesicular arbuscular mycorrhizal? Transactions of the Mycological Society of Japan, 32, 467-476.

[28] Sampath, P. and Sullia, S.B. (1992) The occurrence of VAM fungi in the scale leaves of turmeric. Mycorrhiza News, 14, 5 .

[29] Sangwan, N.S., Farooqi, A.H.A., Shabih, F. and Sangwan, R.S. (2001) Regulation of essential oil production in plants. Plant Growth Regulation, 34, 3-21. doi:10.1023/A:1013386921596

[30] Silva, M.F., Pescador, R., Rebelo, R.A. and Stürmer, S.L. (2008) The effect of arbuscular mycorrhizal fungal isolates on the development and oleoresin production of micropropagated Zingiber officinale. Brazilian Journal of Plant Physiology, 20, 119-130. doi:10.1590/S1677-04202008000200004

[31] Hayman, D.S. and Stovold, G.E. (1979) Spore populations and infectivity of vesicular arbuscular mycorrhizae fungi in new south Wales. Australian Journal of Botany, 27, 227-233. doi:10.1071/BT9790227

[32] Koske, R.E. (1987) Distribution of VA mycorrhizal fungi along a latitudinal temperature gradient. Mycologia, 79, 55-68. doi:10.2307/3807744

[33] Gemma, J.K., Koske, R.E. and Carreiro, M. (1989) Seasonal dynamics of selected species of V-A mycorrhizal fungi in a sand dune. Mycological Research, 92, 317-321. doi:10.1016/S0953-7562(89)80072-3 